\title{
Correction: Transgenic overexpression of endogenous FLOWERING LOCUS T-like gene MeFT1 produces early flowering in cassava
}

\section{The PLOS ONE Staff}

The second author's name in incorrect. The correct name is: Getu Beyene. The correct citation is: Odipio J, Beyene G, Chauhan RD, Alicai T, Bart R, et al. (2020) Transgenic overexpression of endogenous FLOWERING LOCUS T-like gene MeFT1 produces early flowering in cassava. PLoS ONE 15(1): e0227199. https://doi.org/10.1371/journal.pone.0227199.

The publisher apologizes for the error.

\section{Reference}

1. Odipio J, Getu B, Chauhan RD, Alicai T, Bart R, et al. (2020) Transgenic overexpression of endogenous FLOWERING LOCUS T-like gene MeFT1 produces early flowering in cassava. PLoS ONE 15(1): e0227199. https://doi.org/10.1371/journal.pone.0227199 PMID: 31990916

G open Access

Citation: The PLOS ONEStaff (2020) Correction: Transgenic overexpression of endogenous FLOWERING LOCUS T-like gene MeFT1 produces early flowering in cassava. PLOS ONE 15(3): e0231232. https://doi.org/10.1371/journal. pone.0231232

Published: March 26, 2020

Copyright: ๑ 2020 The PLOS ONE Staff. This is an open access article distributed under the terms of the Creative Commons Attribution License, which permits unrestricted use, distribution, and reproduction in any medium, provided the original author and source are credited. 